\title{
Causes and Consequences of Street Life on Homeless Children: Choice or Compulsion?
}

\author{
MAGDA A. MOHAMED, D.N.Sc.*; MANAL F. MOHAMED, D.N.Sc.**; \\ MONA A. HASSAN, D.N.Sc.* and SOHIER G.E. ABD EL-RAHMAN, D.N.Sc.*** \\ The Department of Family \& Community Health Nursing, Faculty of Nursing, Port Said University*, \\ The Department of Pediatric Nursing, Faculty of Nursing, Suez Canal University** and \\ The Department of Psychiatric Mental Health Nursing, Faculty of Nursing, Port Said University***, Egypt
}

\begin{abstract}
Background: Homelessness influences every facet of a child's life. The experience of homelessness inhibits the physical, emotional, cognitive, social, and behavioral development of children.
\end{abstract}

Aim: This study aimed to assess the causes and consequences of street life on homeless children. Overall situation of street children living in Port Said City.

Material and Methods: Descriptive design was used. A sample of 200 homeless children was collected from Port Said City during the period from January to December 2015 non-random sampling technique which includes both snowball and purposive sampling was used.

Tool: An interview questionnaire was the main instrument of data collection developed and it completed by researchers.

Results: The study has revealed that the great majority of street children $(94.5 \%)$ were males, never been attended school and different causal factors have contributed for their street life but, poverty was found to be one of major causes followed by child abuse to push children to move to the street. They were exposed to different types of exploitation and health problems.

Conclusion/Recommendation: The majority of street children faced physical abuse followed by sexual abuses. Drug and substance abuse is very common among street children like cigarette, sniffing glue. So, the study recommended that; awareness raising program should be given for the general public to bring about effective and sustainable change in the lives of these innocent children because street life is viewed as a negative phenomenon by the majority of the societies. Child welfare centers should be supplemented with good infrastructures to accommodate street children.

Key Words: Street children-Causes - Abuse-Child welfare.

Correspondence to: Dr. Magda A. Mohamed, E-Mail: memeybacker@yahoo.com

\section{Introduction}

THE street children phenomenon in Egypt as known for most people is one of Egypt's serious problems. Egypt is a country with the highest number of street children. Despite the lack of conclusive information about street children, many socio-economic indicators show that the phenomenon of street children is growing, especially in large cities as Port Said which considered the main city of attraction for street children $(16.8 \%)$ after Cairo City (31.6\%), followed by Suez (14.3\%), and then Alexandria (6.3\%) [1].

Street child is defined as "any boy or girl under 18 years for whom the street has become his or her habitual abode and/or source of livelihood, and who is inadequately protected, supervised, or directed by responsible adults" [2] street children by the UNICEF: Is divided into children "on" the street and children "of" the streets. Children "on" the streets (home based) are the children whose have home to live in, but they have a full-time work or a part time work but return to their family homes to sleep. Children "of" the streets (street based) are the children "whose home ties have been seriously weakened and who essentially live and sleep in the street" [1]

Homeless children are a global phenomenon that has created countless problems to millions of children in all parts of the world they live a transitory life style and lack basic necessities like food, health care, and a safe place to stay. In the world, street children exist on the margins of society, living in inhumane conditions, suffering from hunger, harassment and physical abuse, deprived of basic services such as education and health care [3]. 
Consequently, they faced different challenges while striving for their survival; they frequently survive by begging, stealing or working in the informal sectors in low paying jobs [4]. The most complex challenge faced by children in the streets was dealing with the perceptions of those around them and the treatment they consequently afforded [5].

It is difficult to estimate the accurate number of street children, because they move around a lot, within and between cities, they are not counted in the national census, educational or health surveys. The best estimated number ranges between 90-150 million worldwide, depending on the exact definition used [6]. In United States, one in thirty children in America is homeless. From 2012 to 2013, in Egypt, the number of street children is believed to be increasing; but as a result of street Children's constant mobility between districts and even governorates, it is extremely difficult to obtain official or reliable statistics on the magnitude of the problem. UNICEF estimates that there are between 200,000 and 1,000,000 homeless children in the country (most of them are in the cities of Cairo and Alexandria). Hope Village Society estimates total number is at around 300,000. Most of the street children are in Cairo and Alexandria. An UNICEF survey held in 2001 shows that $88 \%$ of them come from urban area and $12 \%$ from other areas. The survey on ages reveals that two-thirds of them are 13-16 years of age and one-fourth under the age of 12 [1,7]

In general, there are many factors which can lead to street life. It can be classified into pushing (forcing) and pulling (attracting) factors; pushing factors: Are those inside the family which forced the child to be in the street. Pulling factors: Are those in the street which attracting the child to go to the street. Poverty: Is the number one of the push factors for an increasing number of children on the streets. Parents or guardians send the children to work on the streets to support their families. Others are forced on the streets to find food and shelter. Some children may have been denied a chance to go to school or have dropped out of school and have nothing to do. Family dysfunctional: Is a significant push factor that force children to the street life. In most cases, street children come from broken families due to divorce, separation or imprisonment of the parents. Many families are also increasingly characterized by absence of parents, alcoholism and domestic violence. Many children run away to the streets to avoid violence and abuse in the family [8,9].
In Egypt, the key factors pushing children on to the street are family break up; (divorce, separation, remarriage and death), large family size child abuse and neglect, low income and educational levels, unplanned rural urban migration and children's difficulties in coping with the formal school system and increasing the rate of drop-out. Unhealthy physical environments lead to the high rates of infectious disease and malnutrition among street children [10]. Street children lead harsh lives, commonly engaging in hard labor or illegal activities to earn a living. Lack of proper education will restrict their future job opportunities, trapping them in the vicious cycle of poverty [11]

Street children do not have what society considers appropriate relationships with major institutions of childhood such as family, education and health. The continuous exposure to harsh environments and the nature of their lifestyle make them vulnerable to substance use and this threatens their mental, physical, social and spiritual wellbeing. In many regions, most of these children use alcohol and other psychoactive substances [12]. Violence and maltreatment are mentioned by most street children as a constant feature of their everyday life. It is executed by the police, other law enforcement bodies, employees in social and reformatory institutions, shop keepers and ordinary citizens but also by peers or older street children and adult delinquents who are in contact with street children [13].

Street children are predominantly perceived as immoral, delinquents or even potential criminals. Their general appearance and behavior tend to offend most citizens and local communities often try to push them out of their area. They are thus completely deprived of participating in social and community life. Since it is very hard for street children to obtain legal documents such as birth certificates and identity cards, they are also not able to access government services like school education, vocational training or medical care [14]

The most frequent health problems of street children: Skin diseases (scabies and tinea), anemia, intestinal parasitic infections, skin abscesses and septic wounds, tonsillitis, otitis media and hair lice. Homeless children contract four times as many respiratory infections and twice as many ear infections as housed children. They are also four times more likely to have asthma [15]. Malnutrition is a particular health concern for homeless children, who are twice as likely as housed children to go hungry [16]. Inadequate nutrition sets children up for future problems like cognitive delays and prob- 
lems with academic achievement [18]. Children are also vulnerable to chronic illnesses that disrupt their potential to grow into productive adults [17]

Most studies point to the fact that the majority of street children are smoking and consume illicit drugs, mainly glue, solvents, bango and tablets. Most of them suffer from psychological problems such as depression, anxiety, phobias and antisocial personality disorders which are associated with problems of street life [19].

Homelessness also has devastating effects on the cognitive development and educational success of children. Homeless preschool children are four times more likely than their housed low-income peers to experience developmental delays [15] Types of developmental lags include "delays in language, in reading for school-age children, in personal and social development, and in motor development [20]. Based on the results of the previous studies on homeless children showed that most street children have never been to school and most of them dropped out at primary level. The marginal jobs performed by street children such as selling trivial merchandise, cleaning cars or carrying bags for shoppers do not offer opportunities to learn marketable skills. Street children tend also to spend their money immediately for fear of being robbed. Saving money and planning for any kind of major investments is thus close to impossible $[17,19]$.

These strategies include ways they use to make money, acquire food, and other basic needs. The lifestyle of living on the streets exposes children to a range of harmful situations but they have to battle fiercely to keep alive. Some of them survive by selling whatever they can find. Some even sell themselves, some beg, some steal and so on [21] They can earn money by begging, carrying or bearing, car washing, drug trafficking, juggling, performing music, running errands, scavenging, sex work, and shoe shining or vending [9]. Child beggars fulfill a socially meaningful and valuable role in everyday life. Children mostly beg for money, but they may be given help in kind, including clothing and items of stationary [22]

In Egypt, the NGOs have exerted many efforts to face the phenomena of street children but more work is needed if they want to achieve their target which is eliminating or at least reducing this problem. Laws and legislations should be made to protect street children and help them fit in the society. As to the society more awareness campaigns are needed to get people involved in this problem. Every day we interact with the street children but we always unintentionally neglect them. Sometimes people treat street children as if they are something disgusting or don't exist. That's the reason why awareness campaigns should take place to explain to people that nearly all these children were forced to live on the streets and they didn't choose this themselves and should help them and provide them with a better life [1] .

Nurses must deal with homeless children with have solid nursing skills, strong assessment skills, and the ability to empathize. Should be flexible, a great detective, and culturally sensitive (to race, ethnicity, religion, gender, and sexual orientation, as well as to the culture of poverty and of homeless ness). Must be able to work autonomously and as part of a team in non-traditional settings, have a thorough knowledge of community resources, and be a strong patient advocate. Excellent communication skills and good organizational skills required. Most of all, must be a caring person (AANP, 2004) [23].

\section{Material and Methods}

Therefore, the aim of the present study was to assess the causes and consequences of street life on homeless children.

\section{These specific objectives:}

1- Identify the push and pull factors that expose children to street life.

2- Find out the major problems street children faced in the street life.

3- Determine livelihood activities that street children perform for their survival.

\section{Research question:}

1- What are the pushing and pulling factors that expose children to street life?

2- What are the problems street children faced in the street life?

3- What are the activities that street children perform for their survival?

Design: A descriptive design was used to conduct the study.

\section{Research setting:}

The study was carried out in Port Said City. The mentioned included street children are mainly visible at busy street intersections, in front of supermarkets, mosques, banks, beaches, bus and train station and markets. These children are ex- 
tremely poor and face severe living conditions. They are mostly involved in work activities like street vending, shoe shining, begging, collecting garbage, carrying goods, and so forth.

\section{Sample:}

A total of 200 street children enrolled in this study based on non-random samplings which were snowball and purposive sampling techniques because it was not easy to find an accurate number of street children from which the researcher could select a proper scientific sample by random method and lack of current statistical data in the study area. The snowball sampling technique are used to identify street children and helped to begin with those who were familiar and volunteer to cooperate with the researchers, and then use them to find other friends and colleagues who they know. The main objective of using snowball sampling technique for street children was only to identify them. After identification, the informants from street children were selected through purposive sampling based on their age.

\section{Tool for data collection:}

Tools: An interview questionnaire was developed by the researchers to collect data. Content of tool was determined through an extensive review of literatures and researches which investigate the situation of street children. It consists of two parts: The first part includes socio demographic characteristics (child's age, sex and educational level). The second part includes data related to causes and consequences of street life age, (attracting factors that lead to street life, challenges and problems street child faced and etc.).

\section{Tools validity:}

Tools were submitted to a panel of three experts in the field of pediatric nursing and family \& community health nursing to test the content validity. Modification was carried out according to the panel judgment on clarity of sentences and appropriateness of content.

\section{Ethical consideration:}

Consent was obtained from each street child before starting the study. The researchers introduced themselves to children and informed them about the purpose of this research in order to obtain their acceptance to share in this research and assured that, the research posed no risk or hazards on them. All street children were informed that, participation in the research is voluntary and she/he can withdraw from this research anytime.

\section{Pilot research:}

A pilot study was carried out on $10 \%$ of the total sample to check clarity of items and determine the feasibility of the research. All street children participated in the pilot research were excluded from the research sample.

\section{Field work:}

This study was conducted in a period of 7 months from June 2015 up to December 2015. Researchers collected data all days of week. The researcher was assisted by three research assistants they were post-graduates, each with a Master's Degree in different specialty of nursing science; and all of them were thoroughly trained in using the tool to interview the interviewed consumed about 30-40 minutes for each child. Researchers asked questions in a simple Arabic language and data collection completed by researchers.

\section{Statistical analysis:}

Collected data were coded and tabulated using personal computer. Data were analyzed using the Statistical Package for Social Science (SPSS) Version 33. Quantitative data were expressed as the mean and Standard Deviation (SD) while qualitative data were expressed as frequency and percentage. Monte Carlo test used to obtain an empirical $p$-value. Probability ( $p$-value) less than 0.05 was considered significant and less than 0.01 was considered highly significant.

\section{Results}

The results obtained from the current study are categorized as follows: Demographic characteristics; (Table 1) describes that more than half of street children $(54 \%)$ their ages ranged between 9-12 years, with the mean age of $11.04 \pm 2.0$. The great majority of street children $(94.5 \%)$ were boys and small proportion were girls $(5.5 \%)$. In relation to categories of street children the vast majority of street children $(94.5 \%)$ interviewed were children "of the street", who worked and slept on the streets. While $5.5 \%$ of the street children had homes to go to at night. More than half of them (51.5\%) their parents died both or one and most of street children $(42 \%)$ their mothers heading households.

Table (2) revealed that the most common cause was family poverty (50\%), followed by child abuse (29\%), family breakdown (7.0\%) and sensation seeking $(5.5 \%)$ as pulling cause. So, family poverty takes the lead cause for children's decision to leave home and followed by child abuse. 
Table (3) illustrated that, regarding places street children spend the night and sleep, more than half of them (56\%) sleeping in abandoned building followed by street (37.5\%) and a small group sleeping at work places $(1.0 \%)$. Children who did not spend the night with their families were most likely to sleeping with colleagues (58\%) or sleeping in some places of street with friends (38\%). A small percentage of street children in the sample spent nights alone $(3.5 \%)$ or together with relatives $(0.5 \%)$. The same table showed that the main activities in which children are involved to survive included begging, washing cars and shop windows, collecting plastic and cans from wastes to sell $(57 \%, 13 \%, 16.5 \%$, respectively); selling paper tissues $(4.0 \%)$ and shining shoes $(4.0 \%)$ were among other activities that street children performed most street children of the sample interviewed $60 \%$ stressed that violence represents a major feature of their everyday life and more than half of them $(57 \%)$ exposed to exploitation from other street children or people. Forty-five percentage of street children explained that they were suffering from many health problems. Almost $30 \%$ of the sample stressed that they were suffering from the lack of attachment and affection; and $25 \%$ of the sample considered community disapproval as a major problem they faced on the street. Many street children (13\%) arrested by the police, more than fourth $(27.5 \%)$ of street children were suffering from weather conditions while residing on the street.

Concerning different types of abuse street children exposed; findings pointed that physical abuse was common among $(72.5 \%)$ of street children followed by sexual (15\%) and psychological $(12.5 \%)$ abuse. Regarding to substance abuse the findings revealed that cigarettes were the most common type $(62.5 \%)$, then came sniffing glue $(17.5 \%)$, bango $(7.5 \%)$, tablets $(5.5 \%)$, and $7.0 \%$ used a combination substance. School attendance; findings indicated that $96.5 \%$ of study sample have been never attended school and remaining part $(3.5 \%)$ have dropped out of schools during primary education.

Table (4) reveals the distributions of studied street children according to their faced problems: Children out of school; street children indicated the main reason for not attending school was poor economic conditions at their home $(60 \%)$ and nonnegligible percentage (20\%) of street children expressed their lack of interest in education. Many of street children in the sample cite the effects of loaded in work (42.5\%) and street children's out of school appears to be also linked to family prob- lems, such as broken families (30\%) and bad treatment by teachers $18 \%$ as a cause of their dropping out of school.

Table (5) illustrated that there was statistically significant relationship among different types of abuse street children exposed and their ages. Physical abuse was statistically higher among studied street children who ages between 9-12 years, while sexual abuse was statistically higher among studied street children who ages between 6-9 years.

Table (1): Socio-demographic characteristic of studied street children.

\begin{tabular}{lll}
\hline Socio-demographic characteristic & No. 200 & $\%$ \\
\hline Age/year: & & \\
6 $\geq 9$ years & 36 & 18 \\
$9 \geq 12$ years & 118 & 54 \\
12+ years & 46 & 23 \\
Mean \pm SD & $11.04 \pm 2.0$ \\
Sex: & & \\
Boys & 189 & 94.5 \\
Girls & 11 & 5.5 \\
Categorizes of street children: & & \\
Children on street & 11 & 5.5 \\
Children of street & 189 & 94.5 \\
Parents' relationship of street children: & & \\
Separation & 23 & 11.5 \\
Divorce & 31 & 15.5 \\
Died/both or one of them & 103 & 51.5 \\
Intact & 40 & 20 \\
Unknown & 3.0 & 1.5 \\
Family member responsibility of child care & & \\
(headed households): & & \\
Father & 77 & 38.5 \\
Mother & 84 & 42 \\
Brother/sister & 37 & 18.5 \\
Relatives & 2.0 & 1.0 \\
\hline
\end{tabular}

Table (2): Percentage distribution of studied street children according to the causes of pushing and pulling to street.

\begin{tabular}{lll}
\hline Causes of pushing and pulling street children & No & $\%$ \\
\hline Pushing causes: (In home): & & \\
Family poverty & 100 & 50 \\
Family breakdown/conflict & 14 & 7.0 \\
Child abuse & 58 & 29 \\
Neglect & 5 & 2.5 \\
Pulling causes: (In street): & & \\
Sensation seeking/freedom & 11 & 5.5 \\
Other brother and sister in street & 4 & 2.0 \\
Attracted by city life & 5 & 2.5 \\
Peer pressure & 3 & 1.5 \\
\hline
\end{tabular}


Table (3): Percentages distribution of studied street children according to living conditions.

\begin{tabular}{lll}
\hline Living conditions & No & $\%$ \\
\hline Places where street child sleeping: & & \\
$\quad$ Street & 75 & 37.5 \\
Car bark & 11 & 5.5 \\
Abandoned building & 112 & 56 \\
Work places & 2.0 & 1.0 \\
In street child living with: & & \\
Alone & 7.0 & 3.5 \\
Relatives & 1.0 & 0.5 \\
Friend & 76 & 38 \\
Colleagues & 116 & 58 \\
Activities of street children to survival: & & \\
Begging & 114 & 57 \\
Washing car or shop window & 26 & 13 \\
Collecting plastic/cans from wastes to sell & 33 & 16 \\
Fishing and selling catch & 11 & 5.5 \\
Shining shoes & 8.0 & 4.0 \\
Selling paper tissue or news paper & 8.0 & 4.0 \\
\hline
\end{tabular}

Table (4): Percentage distributions of studied street children according to their faced problems.

\begin{tabular}{|c|c|c|}
\hline Problems & No & $\%$ \\
\hline Violence/abuse: & 120 & 60 \\
\hline Community disapproval & 50 & 25 \\
\hline Police arrests & 26 & 13 \\
\hline Health problems & 90 & 45 \\
\hline Exploitation & 114 & 57 \\
\hline Lack of attachment & 60 & 30 \\
\hline Weather condition & 55 & 27.5 \\
\hline \multicolumn{3}{|l|}{ Types of abuse: } \\
\hline Physical & 145 & 72.5 \\
\hline Psychological & 25 & 12.5 \\
\hline Sexual & 30 & 15 \\
\hline \multicolumn{3}{|l|}{ Substances consumed by street children: } \\
\hline Cigarettes & 125 & 62.5 \\
\hline Sniffing glue & 35 & 17.5 \\
\hline Bango & 15 & 7.5 \\
\hline Tablets & 11 & 5.5 \\
\hline Uses a combination of substances & 14 & 7.0 \\
\hline \multicolumn{3}{|l|}{ Educational background: } \\
\hline Dropped out of school & 54 & 27 \\
\hline Never been to school & 146 & 73 \\
\hline \multicolumn{3}{|l|}{ Causes of dropped out of school: } \\
\hline Economic causes & 109 & 54.5 \\
\hline Family problems & 60 & 30 \\
\hline Bad treatment of teachers & 36 & 18 \\
\hline Lake of interest & 40 & 20 \\
\hline Because of work & 85 & 42.5 \\
\hline
\end{tabular}

*: Number is not mutually exclusive.
Table (5): The relation between the age of homelessness and types of abusive behavior among the study children.

\begin{tabular}{|c|c|c|c|c|c|c|c|}
\hline & & & & GE & & & \\
\hline & & -9 & & -12 & & $2+$ & Test of sig. \\
\hline & No & $\% \mathrm{I}$ & No & $\%$ & No & $\%$ & \\
\hline Physical & 40 & 87.0 & 95 & 88.0 & 36 & 78.3 & $\mathrm{MC}_{p}=$ \\
\hline Psychological & 0 & 0.0 & 1 & 0.9 & 6 & 13.0 & $0.013 *$ \\
\hline Sexual & 6 & 13.0 & 12 & 11.0 & 4 & 8.7 & \\
\hline $\begin{array}{l}\mathrm{MC}_{p}: p \text {-value fo } \\
{ }_{*} \quad \text { : Statistical }\end{array}$ & $\begin{array}{l}\mathrm{r} M \\
\mathrm{ys}\end{array}$ & $\begin{array}{l}\text { te Carl } \\
\text { nificant }\end{array}$ & $\begin{array}{l}\text { o test. } \\
\text { at } p \leq\end{array}$ & $\leq 0.05$. & & & \\
\hline
\end{tabular}

The study findings show that more the vast majority of street children in the present study were boys. This result agreement with Kebede, [8]; Guarcello \& Koseleci, [24] who found majorities who participated in the study were males children living on the street while female constituted a small proportion of the total and explained that, most of the girls do not make conflict with their family members like boys. So that they are not exposed to street life like boys and even those girls who are exposed to street life are involved in prostitution than staying on the street.

Kebede, $[8]$ also, explained the reason as to why number of female street children was small in comparison to male street children as follows: The true incidence of working girls may be hidden by the nature of their work, which tends to be less visible than the work of street boys. For example, females may work as maids in bars, back street hotels and private houses. Street boys, on the other hand, typically engage in more visible activities such as car washing, shoe shining and peddling. From researcher point of view, the predominance of males can be explained by the fact that Egyptian families traditionally tend to keep girls at home more than boys.

The study finding showed more than half of street children their parents both or one died and most of street children their mothers heading households. This result is consistent with the result of street children in Sudan which reported that high proportion of street children were orphaned [25]. Also, the study of street children in Alexandria pointed that $45 \%$ had step parents, $36 \%$ had a mother as the head of the family due to death of father or due to illness of their father.

In relation to categories of street children the vast majority of street children interviewed were children "of the street" (street based) who worked 
and slept on the streets and small proportion of the street children had homes to go to at night. This finding disagreement with Guarcello \& Koseleci, [24] who reported that the first and largest category $(63 \%)$ consists of those children who spend the majority of their time on the streets, but maintain family relations and return home at night.

The findings of this study illustrated that the basic factors pushing children into the street life were family poverty followed by child abuse and family breakdown. Thus, economic and social factors appeared to be primary in pushing children into the streets. This finding supported by Kebede, (2015) [8] who confirmed that poverty as one of the major causes for child street life. Poverty forces children to the streets to support themselves and their families. Poverty is limiting the family's capacity to meet their children's needs forcing children to go to the street to fend for themselves; poverty that is forcing rural population migrate to urban areas, with a hope of better future. Poverty causes malnutrition resulting in poor health and reduces a family's ability to work thus creating a condition for children to move to the streets [7]. In the same line Guarcello \& Koseleci, [24] who confirmed the results but with less or more different in percentages.

Also, the research findings were matched with UNICEF, [1] results that found out a lot of causes for the street children phenomena. Children run away from their homes in Egypt because of child abuse, sensation seeking, neglect, existence of other brothers and sisters on the street and peer pressure. Children say that they were kicked out of their homes and forced to live in the streets and abused by their family or the people they work for. There are a lot of ways for abuse. Abuse usually takes the form of severe beating and insults for small mistakes. A lot of children choose to live on the streets because they feel they are free from any boundaries. A huge number of children said that one of the main reasons for moving to the street life is neglect. It could happen due to the illness of one of the parents, or the presence of a large family, or neglect because of divorce. The existence of other brothers and sisters especially older ones affect their younger siblings to follow their lead and move to live on the streets if their family is facing the problems that they can't handle. Sometimes they move together and look for one another on the streets. Peer pressure acts as one of the most effective methods to increase the street children phenomena. Children explain that peers help them adjust to the life on the streets during their early days on the streets by providing food, entertainment, shelter and protection.

Regarding places street children spend the night and sleep, more than half of them slept in abandoned building followed by street (under the open sky, under bridge, in a drainage pipe, in an unclaimed shelter or in unused railway compartment); and a small group slept at work places. The result consistent with Guarcello \& Koseleci, [24] who reported that street children consider a railway platform, an abandoned house, a garage, an incomplete building, pavement or other such place as their home.

Children who do not spend the night with their families are most likely to sleep with colleagues or sleep in some places of street with friends. A smaller percentage of street children in the sample spend nights alone or together with relatives. These results were not matched with Guarcello \& Koseleci, [24] who indicated that children who do not spend the night with their families are most likely to sleep alone on the streets $(50 \%)$ or to sleep in some places with friends (29\%). A smaller percentage of street children in the sample spend nights at the workplace $(20 \%)$ or in other places together with relatives.

The main activities in which children are involved to survive included begging, washing cars and shop windows, collecting plastic and cans from wastes to sell; selling paper tissues and shining shoes were among other activities that street children performed. These results confirmed with a rapid assessment conducted on street children in Cairo and Alexandria details showed that street children work exclusively in informal sector jobs; that included begging, washing cars and shop windows, selling paper tissues and other items on the streets. Working temporarily in shops or small factories and collecting plastic from wastes to sell to recycling factories were among other activities that street children performed [1]. Because of the lack of protection in these jobs, there is a greater risk of exploitation and of encountering health hazards.

In the same line Kebede, [8] indicated that majority of street children in study were engaged in menial jobs like, carrying goods, shoeshine and street vending (selling small items). And some of them turn to begging as a survival option when they have no other means of activities to sustain themselves. Their life style does not allow them to follow strict and structured hours of work. The 
work of street children falls into that of informal economy. It is irregular and low paid [26].

Once on the streets, children are vulnerable and 'at risk' to all forms of abuse, exploitation and discrimination. This further endangers their life, physical health and psychological well-being. However, they risk of being criminalized for petty theft, involvement in commercial sex, and of being detained by law enforcement agencies [14].

Present study indicated that most street children of the sample interviewed stressed that violence represents a major feature of their everyday life and more than half of them exposed to exploitation from other street children or people. Nearly half of street children explained that they were suffering from many health problems. Also, the lack of attachment and affection plus community disapproval as a major problem they faced on the street. Many street children arrested by the police, more than fourth of street children were suffering from weather conditions while residing on the street.

Anooshian, [27] also, supported findings of the present study and confirmed that living on the streets, with no supervision, protection or guidance often makes street children vulnerable to a wide range of problems or hazards. In particular, because of the nature of continuous exposure to the streets and the associated lifestyles, children are exposed to a wide range of health problems and malnutrition. Most survey respondents reported that violence is a major problem of their daily life. 50\% of street children reported being "disturbed" by the police. Violence on the streets takes many forms from physical violence such as beating (22\% of children in the sample) and conflicts with older children ( $21 \%$ of children) to psychological violence such as insulting (22\% of children in the sample) [8].

Focus group discussions conducted with children living and/or working in the streets of Cairo and Alexandria support also these findings [1] Street children are always at high risk of chronic health problems such as respiratory diseases, parasitic infestations, skin infection, substance abuse and related health problems, as well as exposure to a wide range of other diseases. The unhealthy environment in which street children live and the lack of availability and under-utilization of health services appear to contribute to health problems among street children.

In study survey conducted in Egypt that weather conditions forced most cases of street children to move from area to another in same cities or from city to another to avoid bad weather conditions.
Interviews revealed that many street children move to Alexandria in summer, and move to other governorates, especially Cairo in winter. Data from Alexandria's NGOs show that the number of street children in Alexandria decreases by almost (40\%) in winter due to the weather conditions, while increases occur in summer because of the nature of Alexandria as a summer resort that attracts people from all over Egypt, which gives the children the chance to work, beg and earn a living [1]

Concerning different types of abuse street children exposed; findings pointed that physical abuse was common among of street children followed by sexual and psychological abuse. This finding supported by [8] who found street children suffered in their sleeping places a lot due to cold weather, verbal abuses and physical abuse by gang groups. The most common problems among the street children included harassment by police and hunger. The problem of harassment may consequently give rise to other psycho-social problems such as aggression, fear of society, suspicion, unruliness and theft. Such problems prevent street children from leading peaceful lives [28]

Regarding to substance abuse the findings revealed that cigarettes were the most common type then came sniffing glue, bango, tablets, and small proportion used a combination substance. UNICEF, [1] in research study conducted in Egypt indicated that almost all street children consume substances, which include cigarettes, glue, and tablets (Parkinol). They explained that substance abuse is mainly connected with street life and peer pressure, and a means to endure pain, violence and torture. They explained that being under the effect of substance abuse; they expose themselves to attacks and sexual exploitation [29].

Regarding school attendance; findings indicated that the great majority of study sample have been never attended school and remaining part have dropped out of schools during primary education. This result was matched with finding of a similar study conducted in Egypt; data on the educational levels of street children indicated that $70 \%$ of the sample dropped out schools during their primary education, $30 \%$ of them have never attended schools [1].

Also, the research finding was congruent with results of Guarcello \& Koseleci, [24] survey which showed that most street children in the sample were deprived of basic education. Only $27 \%$ of street children are attending school, $43 \%$ of children in the sample have dropped out from school, and 
finally, $28 \%$ of survey respondents have never been at school. Reasons of children out of school indicated that less than two thirds of street children their main reason for not attending school was poor economic conditions at their home and many of street children expressed their lack of interest in education. Less than half of street children in the sample cited the effects of loaded in work and non-negligible proportion of Street children's out of school appears to be also linked to family problems, such as broken families and bad treatment by teachers as a cause of their dropping out of school.

Guarcello \& Koseleci, [24] agreement with these results and reported that the main reason for not attending school were poor economic conditions at their home among $45 \%$ of the sample, $30 \%$ reported that their parents were not willing to send them to school, and $21 \%$ express their lack of interest in education. A small percentage of street children in the sample cited the effects of involvement in work (18\%) and bad treatment by teachers $(16 \%)$ as a cause of their dropping out of school. Also, family problems were considered one of reasons of street children's school nonattendance.

Finally, findings illustrated that there was statistically significant relationship among different types of abuse street children exposed and their ages. Guarcello \& Koseleci, [24] confirmed this finding and reported that young age of street children especially girls obviously increased their vulnerability to sexual exploitation and to both physical and sexual abuse. They are faced with extremely harsh conditions including sexual abuse by adults, unwanted pregnancy and early motherhood-sometimes as young as 12 and are highly at risk of being infected with HIV/AIDS [30].

Also, all the study sample of street children interviewed stressed that they did not obtained any help or support from governmental and NonGovernmental Organizations (NGOs). And this result was supported by UNICEF, finding that reported the children of the samples interviewed had not heard of any programs provided by NGOs or GOs to deal with substance abuse among street children [31].

\section{Conclusion:}

Based on the finding of the study it will be concluded that:

The great majority of street children were males, never been attended school and different causal factors have contributed for their street life. Poverty and conflict with their guardians was found to be major causes followed by physical abuse and sexual abuses. Death of parents, family breakdown, peer pressure, large family size and lack of parenting skills were also another significant factor contributing to street life. The majority of street children faced drug and substance abuse like cigarette, sniffing glue.

\section{Recommendation:}

Based on the finding of the study: The following recommendations are suggested:

Awareness raising program should be given for the general public to bring about effective and sustainable change in the lives of these innocent children because street life is viewed as a negative phenomenon by the majority of the societies. Conducting more researches in the other city in Egypt to identify the magnitude of the problem against street life. Child welfare centers should be supplemented with good infrastructures to accommodate street children.

\section{References}

1- UNICEF: Rapid Situation Assessment of Street Children in Cairo and Alexandria. Egypt. https://www.unodc.org/ pdf/youthnet/egypt_street_children_report.pdf Accessed 2016-02-16, 2001.

2- National Center for Homeless Education: Children and Youth Experiencing Homelessness: An introduction to the issues; pp. 2-4, 2014.

3- UNICEF: A Base Line Survey of Children Living on the Street of Addis Ababa, 2007.

4- ZENA A. and ANETH K.: Coping Strategies Used by Street Children in Time of Illness. Dareselaam, Tanzania, 2010.

5- OHCHR: Protection and Promotion of the Rights of Children Working and/or Living on the Street. Geneva, Switzerland, PP. 16-24, 2011.

6- KIDD, SEAN A. JEFF KARABANOW, JEAN HUGHES and TYLER FREDERICK: Brief report: Youth pathways out of homelessness-Preliminary findings. Journal of Adolescence, 36: 1035-7, 2013.

7- PATTERSON, MICHELLE L. LAUREN CURRIE, STEFANIE REZANSOFF and JULIAN M. SOMERS: Exiting Homelessness: Perceived Changes, Barriers, and Facilitators Among Formerly Homeless Adults with Mental Disorders. Psychiatric Rehabilitation Journal, 2014.

8- KEBEDE S.H.K.: The Institution of Street Children in Urban Centers of Ethiopia and the Role of NGOs in Addressing their Socio-Economic Problems: The Case of Hawssa City. International Journal of Academic Research in Education and Review, (3) 3: pp. 45-7, 2015.

9- MILBURN, NORWEETA G. LI-JUNG LIANG, SUNGJAE LEE and MARY JANE ROTHERAM-BORUS: Trajectories of risk behaviors and exiting homelessness among newly homeless adolescents Vulnerable Children 
and Youth Studies, Vol. 4, No. 4, December 2009, 34652, 2013.

10- UNICEF: The State of the World's Children. Excluded Invisible: New York, 2006.

11- JICA: Street Children Support Development Project in Egypt, 2009.

12- OJELABI and OYEWOLE O.: Economic Factors as Correlates of Streetism among Urban Children in Ibadan Metropolis, Nigeria, 2 (9), 2012.

13- MARIE W.: Consortium for Street Children Background Paper on Street Children and Panel Discussion on Violence Against Children on Monday, April 9, 2001.

14- National Center for Children in Poverty: Columbia University Mailman School of Public Health. United States Demographics of Low-Income Children. Accessed June 8, 2009 from http://www.nccp.org/profiles/state_ profile.php?state=US\&id=6, 2009.

15- National Center for Family Homelessness: Children. http://www.familyhomelessness.org/children. Php? p=its Retrieved December, 2012.

16- National Center on Family Homelessness: America's youngest outcasts: State report card on child homelessness. Newton, MA, 2009.

17- TOBIN K. and MURPHY J.: Addressing the challenges of child and family homelessness, 2013.

18- PARSELL CAMERON, WOJTEK TOMASZEWSKI and RHONDA PHILLIPS: Exiting Unsheltered Homelessness and Sustaining Housing: A Human Agency Perspective, Source: Social Service Review, Vol. 88, No. 2 (June 2014), pp. 295-321, 2014.

19- National Coalition for the Homeless: Homeless youth, NCH Fact Sheet \#13. Washington, DC: Author, 2008.

20- HERBERS J., CUTULI J., SUPKOFF L., HEISTAD D., CHAN C., HINZ E. and MASTEN M.: Early reading skills and academic achievement trajectories of students facing poverty, homelessness, and high residential mobility. Educ. Res., 41 (9): 366-74, 2012.

21- SHERMAN: Drug Use, Street Survival, and Risk Behaviors among Street Children in Lahore, London: Oxford University Press, 2005.
22- TATEK A.: The Survival Strategies of Ethiopian Child Beggars: Addis Ababa, Ethiopia, 2009.

23- American Academy of Nurse Practitioners: U.S. Nurse Practitioner Workforce 2004. www.aanp.org , 2004.

24- GUARCELLO L. and N. KOSELECI: A profile of Cairo street children. Understanding Children's Work Programme Working Papers Series, November 2009 Rome. http:// . www.ucwproject.org/attachment/street children Cairo 20110517_145508. pdf Accessed 2016-07-19, 2009.

25- ADAM A.I.: Assessment of Common Health Problems, Nutritional Status and Social Aspects of Street Children in Rehabilitation Centers in Khartoum. University of Khartoum, Faculty of Medicine. Post Graduates Studies Board, 2005.

26- ILO: A Future Without Child Labor. General Report Under the Follow-Up to the ILO Declaration on Fundamental Principles and Rights at Work. International Labor Conference, $90^{\text {th }}$ Session, Geneva, in Egypt, Land Centre for Human Rights (LCHR), 2002.

27- PATTERSON, MICHELLE L., LAUREN CURRIE, STEFANIE REZANSOFF, and JULIAN M. SOMERS: Exiting Homelessness: Perceived Changes, Barriers, and Facilitators Among Formerly Homeless Adults with Mental Disorders, Psychiatric Rehabilitation Journal () 2014 American Psychological Association 2015, Vol. 38, No. 1, 81-7, 2015.

28- LEE B.A. and GREIF M.J.: Homelessness and Hunger. Journal of Health and Social Behavior, 49 (1): 3-19, 2008.

29- American Academy of Pediatrics: Providing care for immigrant, homeless, and migrant children. Pediatrics, 115 (4): 1095-100, 2005.

30- TODD C. CAMP BELL and DARNELL DURRAH: Homelessness: An Unnatural Disaster. APA Handbook of Counseling Psychology: Vol. 2. Practice, Interventions, and Applications, Nadya A. Fouad (Editor-in-Chief) 2012 by the American Psychological Association, 2012.

31- WEAVER J.D.: Beyond Child Welfare-Theories on Child Homelessness; Washington and Lee Journal of Civil Rights and Social Justice, 21: pp. 3-7, 2014. 


\section{آسباب وتبعات حياة آطفال الشوارع اللذين بلا مآوى: إضطرارى آم إختيارى الخوارع}

مقدمة: ظاهرة آطفال الشوارع في مصر هي واحدة من المشاكل الخطيرة. وتعد مصر من آكبر الدول التى تشهر آكبر عدد من آطفال

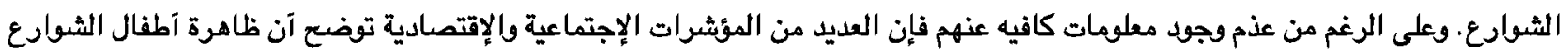

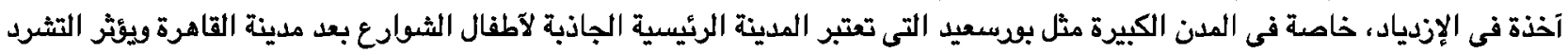
على كل جانب من جوانب حياة الطفل فهو يمنع التطو البدنى والعاطفى والمعرفى والإجتماعى والسلوكى للآطفال.

هدف البحث: تهدف هذه الدراسة إلى دراسة آسباب وتبعات حياة آطفال الثوارع الذين بلا مآوى والمشردين الذين يعيشون فى مدينة

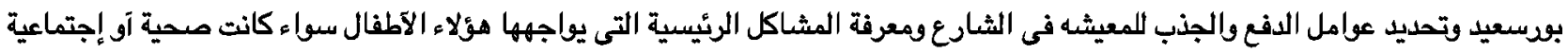

$$
\text { منهج البحث: إستخدمت الدراسة الوصفية. }
$$

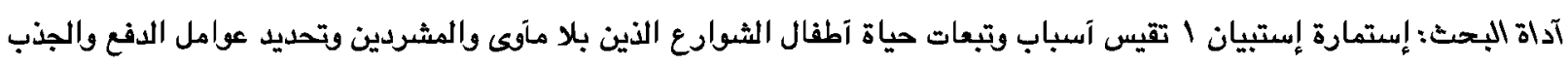

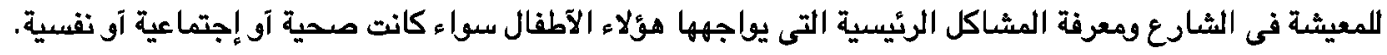

نتائج البحث: كثفت الدراسة آن الغالبية العظمى من آطفال الشوارع هم من الذكو، ولم يلتحقوا آبدا بالمدارس، وقد ساهمت عوامل

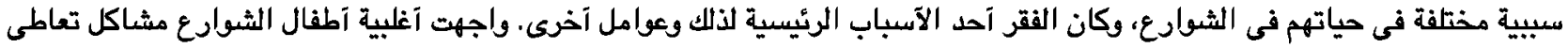
المخدرات والسجائر، وإستنشاق الفراء وإضطهاد المجتمع كما وآن العديد منهم آعتقلتهم الثرطة.

الخلاصدة والتوصيات: واجهت آغلبية آطفال الشبوارع بمدينة بودسعيد الإيذاء البدنى تليها الإعتداءات الجنسية. تعاطى المخدرات وتدخين

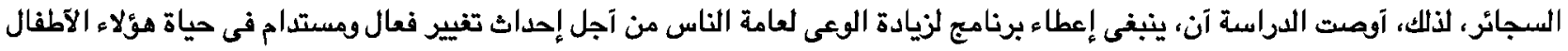

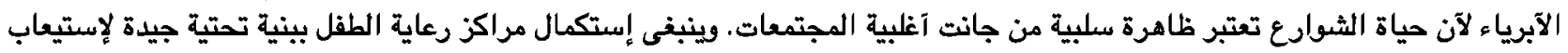

